\title{
Income diversification strategies among pastoralists in Central Asia: Findings from Kyrgyzstan
}

\author{
Rahat Sabyrbekov ${ }^{1,2}$ (D)
}

\begin{abstract}
The loss of land productivity is one of the key challenges facing land use policy-makers worldwide. Pastoralist societies are particularly vulnerable to the loss of land productivity due to their dependence on pastures to raise livestock. Decreasing this dependence through the diversification of livelihood strategies could potentially reduce the vulnerabilities of such societies, with the added benefit of reducing livestock pressure on pastures. This study examines on-pasture income diversification strategies among Kyrgyz pastoralist societies and aims to identify which factors lead to tourism engagement as a non-livestock pasture-related income source. Both individual household and regional (rayon) features associated with diversification are investigated, as are factors such as the perceived high levels of pasture productivity loss. The results show that the income diversification among households differs depending on the number of head of livestock a household owns, regional differences and whether a household manages livestock belonging to others. In addition, the study found no statistically significant result that would show that high perception of pasture degradation would lead to adoption of non-livestock livelihoods, i.e. tourism.
\end{abstract}

Keywords: Land use, Pasture, Productivity loss, Diversification, Central Asia, Kyrgyzstan, Tourism, Degradation

\section{Introduction}

Pasture ecosystems are highly vulnerable to external influence and are under heavy pressure in countries where livestock herding remains a major livelihood strategy (Zika and Erb 2009; Tarrasón et al. 2016). These lands are an important part of the well-being of many societies across the globe, supporting approximately 200 million people worldwide (Davies and Hatfield 2007; O'Mara 2012). Pastures also have cultural importance for the local population and for those outside of the pastoralist communities (Genovese et al. 2017). Additionally, from a climate regulation standpoint, pastures around the world serve as an immense perpetual global carbon sink (Smith 2014). However, over-grazing, manifested as a loss of productivity, is typical in many parts of subSaharan Africa, Central Asia and Latin America (Schauer et al. 2015; Preston et al. 2003; Mirzabaev et al. 2016).

Correspondence: rahat.sabyrbekov@nmbu.no; sabyrbekov_r@auca.kg ${ }^{1}$ Economics, American University of Central Asia, 7/6 Aaly Tokombaev Street, 720060 Bishkek, Kyrgyz Republic

${ }^{2}$ School of Economics and Business, Norwegian University of Life Sciences, Campus Aas, Universitetstunet 3, 1433 Aas, Norway
The reasons for declining pasture productivity are seemingly straightforward. Human-induced degradation has been attributed to over-grazing or other damaging land-use practices (Hilker et al. 2014; Stevens et al. 2016; Kairis et al. 2015; Christianen et al. 2014; Gaitán et al. 2018). Often, the common property nature of pastures causes Garret Hardin's tragedy of commons (Hardin 1968), where multiple users compete for the resource. In competition for fodder and lacking other livelihood strategies, pastoralist societies often disregard stocking density norms. At a global level, the response to this declining productivity has led to the emergence of new global initiatives such as Sustainable Land Management programmes, the Economics of Land Degradation Initiative and Land Degradation Neutrality among others. But the fruits of these initiatives have yet to be seen at the local level in areas where they have been introduced (IPBES 2018).

Theoretically, the loss of pasture productivity can be halted if the pressure on the ecosystems is reduced, i.e. by decreasing the number of head of livestock or improving grazing practices. However, it is challenging to 
persuade households to limit or decrease the number of livestock when livestock production remains their primary income source and is the dominant livelihood strategy. An alternative livelihood strategy is the introduction of a nonagriculture-based activity that can compensate for or replace the decrease in income resulting from decreased livestock numbers. The falling pasture productivity theoretically could force the households to adopt new livelihood strategies. Thus, income diversification in areas with high pressure on natural pastoral ecosystems has become a high priority and a necessity in many developing countries (Martin and Lorenzen 2016; Addisu 2017; Boncinelli et al. 2018).

The development of non-agricultural employment is on the policy agenda of many governments and seen as a pathway out of rural poverty. An increase in nonagricultural employment is also associated with higher economic productivity. As in countries with higher income per capita, the share of agriculture in the total economy is typically in the single digits. Thus, the growth of the non-agricultural sector is desirable by policy-makers on a macro level as well.

The literature on the drivers of income diversification among pastoralists highlights many factors that lead to the adoption of new livelihood strategies; this has been well-documented around the world (Watson and van Binsbergen 2013; Addisu 2017; Gecho 2017). These factors include individual household features such as household size, education of the head, number of assets, total income and individual uncertainty or risk perception. External factors also influence income diversification, particularly large-scale social and economic transformations such as state policy changes or changes in the overall practices associated with herding. The existence of new income opportunities in the villages may also be due to increased labour demand, the availability of infrastructure such as roads, access to financial services and/or physical proximity to markets with increased overall development. Often, the high heterogeneity present in all aspects in rural communities in terms of features such as asset allocation, education, skills, spatial characteristics and institutional quality challenges a successful income diversification policy (Haggblade et al. 2009).

The literature divides income diversification into two types: 'distress-push' or 'distress' diversification and 'demand-pull' or 'progressive' diversification (Liu and Lan 2015). An example of distress-push diversification would be a situation in which the falling profits from agricultural activities force members of a household to look for nonagriculture-based jobs to make ends meet (Liao et al. 2015). Income diversification causes distress because it is often the case that poorer households are more vulnerable to external shocks such as a sharp drop in agricultural product prices and the incidence of diseases or natural disasters.
Demand-pull diversification refers to a situation in which a household adopts a new income source because of access to new opportunities or a decrease in risk. Income diversification in this case is mainly exercised by richer households that have more assets and which are less vulnerable to the potential risks of branching out (Gecho 2017; Martin and Lorenzen 2016).

Diversification is important for pastoralist societies because of the elevated risks related to the high levels of uncertainty stemming from factors such as environmental changes, livestock diseases and price volatility for livestock products. Herders can diversify income in two ways. First, they can diversify livestock composition to address the risks associated with sector specialization. Second, they can engage in income-generating activities that do not involve herding livestock, such as tourism.

Few studies have researched pasture-related income diversification in pastoralist societies in Central Asia (Kazakhstan, Kyrgyzstan, Tajikistan, Turkmenistan and Uzbekistan), a region that is home to one of the largest populations of pastoralist societies. While many researchers study the income sources of pastoralists (Kerven et al. 2011; Ilibezova et al. 2005), or their onand off-farm income diversification strategies (Schoch et al. 2010), no studies appear to address on-pasture income diversification in Central Asia. On-pasture income diversification is important because it requires less drastic changes of lifestyle. For example, on-pasture income strategies, such as providing tourism services, can be combined with the traditional livelihood strategies such as herding and do not require emigration.

This study examines the on-pasture diversification strategies in Kyrgyz pastoralist societies. The main research question is to identify which factors lead to onpasture diversification. Specifically, it is to study whether income diversification is affected by types of herding (i.e. managing one's own herd or managing a mixed herd, one's own and someone else's herd), a household's total income, the household's perception of pasture productivity loss, (district) rayon-specific features and other household features. Finally, the self-reported data are matched with the official data on the loss of pasture productivity to see how to address the ongoing debate on the extent and existence of the pasture degradation in Kyrgyzstan.

\section{Pasture development in Kyrgyzstan}

Kyrgyz pastures are vital for the livelihoods of rural Kyrgyz communities which comprise most of the country's population. A semi-arid and mountainous country, $85 \%$ of the agricultural land in Kyrgyzstan is pasture land (Land Cadastra of the Kyrgyz Republic 2015). Historically, pastures have held an important meaning in the lives of the local populations. Livestock grazing in 
Central Asia is an indivisible part of local history, culture and economy. Grazing in Kyrgyzstan is organized to be mobile and seasonal, with herders moving their stocks to high altitude pastures in summer and down to the lower lying valleys in the cooler seasons. These vertical movements are subject to a number of institutional, social, biophysical and economic factors (Liechti 2012; Ludi 2004).

The loss of pasture productivity is a major agricultural and economic policy concern. The pastures feed most of the country's livestock, thus providing the main source of income for the majority of the country's population. The causes of the loss of pasture productivity in Kyrgyzstan include both environmental factors, such as changes in weather patterns, and anthropogenic factors, such as grazing practices (Mirzabaev et al. 2016; Zhumanova et al. 2016). Regardless of the cause, what is certain is that the pastoralist societies of Central Asia could benefit from more sustaitainable land management practices to preserve pastures and related strategy.

During Soviet times, collective farms managed the pastures, and despite high stocking density, land productivity was largely preserved through regular monitoring and investment. The break-up of the Soviet Union in the 1990s led to changes in the institutional structures of pasture management (Kerven et al. 2016; Ludi 2004). The economic crisis which followed the collapse of the Soviet Union resulted in a significant reduction in the number of livestock and, hence, the abandonment of high altitude pastures and widespread rural-to-urban migration. In the years since independence in 1991, the Kyrgyz economy has seen an increase in economic growth and incomes, but it has not led to reduced herd sizes. On the contrary, the growth of GDP per capita has been accompanied by an ever-increasing number of livestock (Tilekeyev et al. 2016). This is no surprise as livestock is regarded as a form of living cash and, thus, as a savings vehicle. Thus, once the economy started regaining its momentum in the 2000s, the amount of livestock began increasing steadily (Liechti 2012) and pasture degradation became an issue (Pasture Department 2015).

According to the official data, about $70 \%$ of Kyrgyzstan's natural pastures are now degraded (Pasture Department 2015). The extent of the degradation and even the understanding of the term are questioned by some authors (Levine et al. 2017). However, the degradation has also been confirmed by independent normalized difference vegetation index (NDVI)-based studies using remote sensing (Mirzabaev et al. 2016). Levine et al. (2017) also confirmed that NDVI data largely supports the incidence of degradation with few caveats and reported that the analysis could benefit from the use of local ecological knowledge. This paper refers to the degradation as the loss of pasture productivity.
Policy-makers in Central Asia are now faced with a tangled web of formal and informal institutions, as well as biophysical, social and economic factors, related to pasture management (Kerven et al. 2016; Robinson et al. 2016; Sneath 2003; Hauck et al. 2016). In an attempt to stop the degradation in Kyrgyzstan, institutional pasture management moved from being central and hierarchical to a local, community-based pasture management (CBPM) system in the early 2000s. The CBPM system established local pasture management groups, jayit komitet, who develop pasture use and development plans. Pasture degradation through over-grazing has often been linked with low skill level and knowledge among herders, excessive livestock and weak pasture management institutions (Ludi 2004; Kerven et al. 2011). Hence, government policy, with the support of international NGOs, has been focused on local institutional development of the jayit komitet and capacity-building for herders to adopt improved pasture management techniques. Perhaps, it is still too early to evaluate the results of the move to the CBPM system, but its local legitimacy and vulnerability to local power structures has already come under discussion (Dörre 2015).

\section{Study area}

The site was chosen within the Economics of Land Degradation Initiative Study of Central Asia (Quillerou et al. 2016) as a representative site to study the current highland pasture land use practices in Kyrgyzstan, using the ecosystem services framework. The Son Kol Lake pastures are one of the largest pastures, located in central Kyrgyzstan at an altitude of $3016 \mathrm{~m}$ above sea level. In terms of vegetation and land use, the site is similar to many high altitude Kyrgyz pastures, constituting $45 \%$ of the total area of pasture lands in the country (Semenova and Chortonbaev 2014).

The area, covering 103,300 ha, includes 98,100 ha of land and 5200 ha water (Fig. 1). The lake freezes in late October or early November. Son Kol has cold winters and short warm summers. The vegetation cover of the Son Kol basin is mainly comprised of fescue.

Son Kol is primarily used for grazing during summer and, in recent years, has become a popular destination for international and domestic tourism, in part due to the organization of community-based tourism in the early 2000s. Part of the Son Kol area belongs to the Karatal-Japryk National Park. ${ }^{1}$ Four municipal districts $\left(\right.$ rayons $\left.^{2}\right)$ : Naryn, Ak Talaa, Jumgal and Kochkor, share

\footnotetext{
${ }^{1}$ The study is not concerned with the national park, and the details (e.g. map and area) of the park are not discussed in this paper. It would be appropriate to expect that a household's proximity to the national park provides a household an opportunity to engage in tourism-related, income-generating activities.

${ }^{2}$ Kyrgyzstan consists of seven provinces - oblasts, which are divided into municipal districts-rayons.
} 


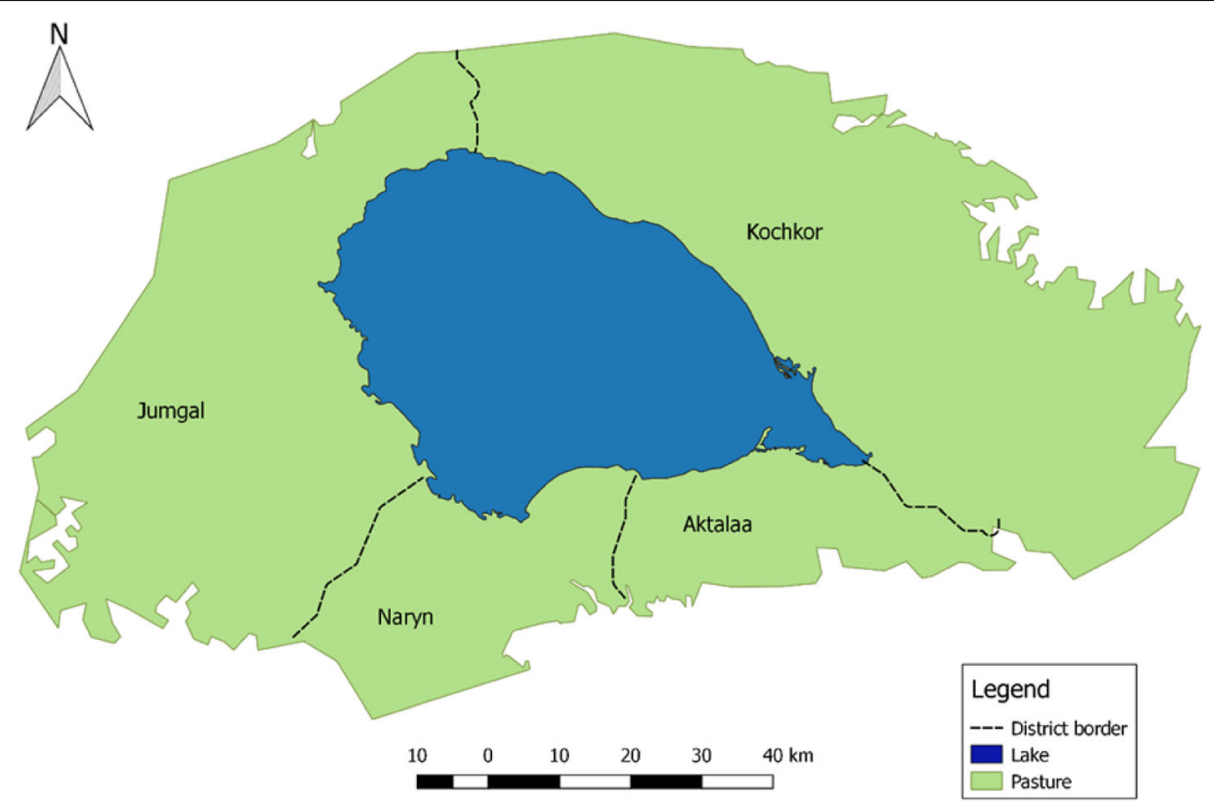

Fig. 1 Map of Son Kol lake pasture and four districts. Source: Kyrgyz State Cadastral

the Son Kol pastures. Table 1 presents the selected characteristics of the four districts and summary statistics of livestock holdings from the households interviewed. Naryn is the largest of the rayons by area but ranks third by population density. Kochkor has the lowest unemployment rate which coincides with the largest livestock numbers, suggesting there is more work related to livestock herding. Jumgal herders have the largest share of own livestock (57\%), while for the remaining three rayons the share ranges between 20 and 33\%.

Table 1 General characteristics of the four rayons and household-specific statistics

\begin{tabular}{|c|c|c|c|c|}
\hline & Aktalaa & Jumgal & Kochkor & Naryn \\
\hline Population density per sq. km & 4.8 & 8.2 & 9.1 & 5.6 \\
\hline Area sq. km & 6407 & 5221 & 6407 & 7842 \\
\hline Unemployment in percent & 8.1 & 12.3 & 7.3 & 10.2 \\
\hline $\begin{array}{l}\text { Distance from rayon centre to } \\
\text { the capital }(\mathrm{km})\end{array}$ & 413 & 322 & 196 & 315 \\
\hline \multicolumn{5}{|l|}{ Household-level information } \\
\hline $\begin{array}{l}\text { Number of households } \\
\text { interviewed }\end{array}$ & 17 & 22 & 34 & 12 \\
\hline $\begin{array}{l}\text { Total animals (in LU, own } \\
\text { and others) }\end{array}$ & 6595 & 3256 & 16,586 & 5076 \\
\hline $\begin{array}{l}\text { Animals owned by household } \\
\text { (in LU) }\end{array}$ & 1427 & 1863 & 5619 & 1032 \\
\hline $\begin{array}{l}\text { Animals managed for others } \\
\text { (in LU) }\end{array}$ & 5168 & 1393 & 10,949 & 4047 \\
\hline $\begin{array}{l}\text { Mean livestock unit per household } \\
\text { (in LU, others and own) }\end{array}$ & 388 & 148 & 423 & 487 \\
\hline
\end{tabular}

Source: National Statistics Committee, author's survey data
Each rayon has an allocated area, and all herders know the borders for their rayon, but trespassing is common. Households move to Son Kol in spring from their villages and stay until the end of summer. Son Kol herders have three income sources: (1) salary for tending somebody's else's livestock (either as a fixed salary or a per head payment); (2) sales of livestock and livestock products (primarily mare's and cow's milk); and (3) nonlivestock-based income (including wages for on-demand services related to tourism). Some households manage only their own livestock herd so their income is limited to two sources. Those households tending their own livestock are referred to as 'owners' while those who manage others' livestock, in addition to their own, are referred to as households with 'mixed herds'. Sales of livestock products are made to intermediaries who collect the livestock from the herders to sell at local markets in nearby cities. The provision of tourism services includes horseback riding, accommodation in traditional yurts and serving meals.

Despite their economic and cultural importance, Son Kol pastures have continued to lose their productivity. Intensive grazing has caused an adverse change in the composition of grass species, resulting in a decrease in forage grass and a dramatic increase in non-forage weed-type plants (Pasture Department 2015).

\section{Methods and materials} Household survey

The questionnaire consisted of four modules with questions gathering different information on the household: (1) socio-economic information; (2) the use of Son Kol 
pastures, including detailed information about livestock ownership; (3) tourism; and (4) the time spent in the village of origin. The questionnaire was in Kyrgyz language and was later translated into English. During the summer of 2015, 90 face-to-face household interviews were conducted using semi-structured questionnaires at Son Kol Lake. After dropping incomplete ones, 85 questionnaires remained for the analysis. Prior to the field work, the questionnaire was piloted and improved. Students from the American University of Central Asia conducted the interviews after they received training by a professional sociologist on data collection and questionnaire administration. All data and the questionnaire are available upon request.

The study is based on the household survey. Laslett and Wall (1972) traced the evolution of the definition of family and household and showed how it changed from kinship to territoriality (Goody 1972). Globally, the increase of household members' mobility has led to the household multi-locality phenomena (Schier et al. 2015; Weichhart 2015). In the Kyrgyz context, multi-locality is important due to the rate of high internal and external migration (Thieme 2014). In relation to the research questions of this study, respondents were asked explicitly about the remittances from off-village family members. However, only two households reported receiving remittances. Thus, in this study the term 'household' refers to a group of people living together, including persons currently living together at pasture and those who remain back in the village. Livestock units (LU) are based on the national regulations, where one sheep equals one LU and cattle is four LU. The LU are provided strictly for the livestock ownership comparison since the study does not assess the pasture capacity.

\section{District level and pasture productivity data}

Additional non-survey-based demographic data on the four rayons were also collected. The data includes socioeconomic information such as population size, unemployment rate, geographical area and the distance from Son Kol to the district's main city as reported in Table 1 . All district data comes from the official local and national government statistics offices.

Pasture productivity data were obtained from the National Soil Institute (Giprozem) archives. The institute collects and weights dry matter from representative sites in centners per hectare and identifies the edible share (as compared to the long-term historical natural productivity levels) to estimate the productivity level on an annual basis accounting for weather variability. The Methodology Guidelines for Pasture Management were approved by government decree, Number 148, dated 5 October 2004. Despite some criticism for lack of openness and availability (Robinson 2016), Girprozem remains the only source of national official data. In this study, I also compare the Giprozem's data on productivity with herders' perceptions on the loss of productivity of their pastures, because those may be different and could play a role in the herders' livelihood diversification decisions.

\section{Statistical tools \\ Diversification indices}

Two diversification indices were used. The Shannon index, a well-accepted diversity measurement used in biology, accounts for equity and richness of species and measures livestock diversity (Spellerberg and Fedor 2003; Shannon and Weaver 1949). The index is determined by the equation:

$$
H=-\sum_{i=1}^{n} p i \ln p i
$$

where $H$ is the Shannon index, $p i$ is the proportion of species $i$, and $\ln p i$ is its natural logarithm. For this study, the Shannon index will assess the diversification level of the livestock composition.

The Herfindahl-Hirschman Index (HHI) is a concentration measurement score used to measure income diversification and is commonly used in such studies (Rosenbluth 1955; Hirschmann 1964). The HHI is determined by the equation:

$$
\mathrm{HHI}=\sum_{i=1}^{n}\left(\mathrm{IS}_{i}\right)^{2}
$$

where $\mathrm{HHI}$ is the income diversification index and $\mathrm{IS}_{i}$ is the share of income derived from activity $i$. A high $\mathrm{HHI}$ score indicates higher concentration and therefore less diversification. The index takes a maximum value of 10,000 for a household that derives revenues from a single source (livestock herding), and so a lower HHI means a higher income diversification level. The HHI calculation includes livestock and non-livestock income sources.

The regression was used to check the effect of the total household income on the HHI. To satisfy the regression validity requirements, the income was transformed into the natural logarithm and diagnostics tests were performed. To test the non-linear effect of income, I used quadratic function of the income logarithm. Additionally, for this purpose, I used graphical analysis of income quintiles using the xtile STATA command and plotting against the HHI.

\section{Tourism income}

A logistic regression is estimated for tourism engagement to see the effect (if any) on household features, location, car and livestock ownership and pasture 
degradation perception. The logistic regression uses maximum likelihood estimation to calculate the probability of a dichotomous event and is widely used in diversification studies (e.g. Dinku 2018; Liao et al. 2015; Gecho 2017). To assess the model, the link test is used for model specification error and the Hosmer-Lemoshow tests for the goodness of fit of the model.

Statistical analysis also included standard variability analysis tools for household features, ANOVA and ANCOVA tests and graphical Kernel density distribution analysis for owners and mixed households using STATA 13 and SPSS.

\section{Results}

\section{Main income sources}

The survey revealed that households in Son Kol had income from various sources, classified as livestock and non-livestock income. Herders are divided into two types, own-herd and mixed-herd households. The livestock income includes salaries for tending others' livestock and revenues from sales of live animals and livestock products. Non-livestock income involves activities related to tourism. In addition, households also received subsidies from the government in the form of child allowances and old age pensions. Subsidies and remittances were excluded from the $\mathrm{HHI}$ analysis of income diversification because subsidies are not an intentional household livelihood strategy and the sample had only two remittance-receiving households that benefitted from such transfers on an irregular basis.

Table 2 presents household income by source and by type of households, i.e. own-herd households and mixed-herd households. In total, 26 households (31\% of the total) managed only their own livestock and 59 herders $(69 \%$ of the total) had mixed herds. The mixed-herd households either receive a per livestock head monthly payment or a fixed salary. Most households $(78 \%)$ received a per head payment, while four (7\%) had fixed salaries, and nine (15\%) did not receive any payment. Those not paid were typically herding the livestock of a close family member. On average, herders received a monthly payment per head of $35 \mathrm{KGS}^{3}$ (0.5 USD) per sheep, $200 \mathrm{KGS}$ (3 USD) per cow, and 234 KGS (3 USD) per horse. A mixedherd household managed twice as many animals belonging to others, on average, than their own livestock. Thus, the salary was an important supplement to the household's income.

At the rayon level, the difference between the share of others' and own livestock is more striking, and the largest differences in mean numbers are seen in Ak Talaa and Naryn. The only exception is in Jumgal district,

${ }^{3} 1$ US dollar $=69 \mathrm{KGS}$ at the time of the survey which shows a lower difference between the amount of own and others' livestock in the herds.

\section{Livestock-based income}

The other two livestock-based income sources are the sale of livestock products (mare's and cow's milk) and sale of live animals. During summer, the herders sell mare's and cow's milk to intermediaries who collect the milk and take it down to the valley to sell at local town markets. Herders also sell a small share of the milk to tourists. Throughout the year, the households also sell live animals. Sixty-nine households (81\%) derived income from the sale of live animals, with a mean monthly income of 17,791 KGS (258 USD) for own-herd and 16, 796 KGS (243 USD) for mixed-herd households. The sale of livestock products was the second most popular option, with 67 households (79\%) utilizing this strategy, as compared to 50 households (59\%) deriving income from livestock tending fees. When these three livestockbased sources are compared in terms of the highest mean income they provide, livestock sale income of herders have the highest mean of 17,791 KGS (258 USD). The sale of livestock products brought in the least mean income of 6712 KGS (97 USD) for mixed-herd pastoralists. However, when total mean incomes are compared, the households who sold live animals (i.e. households who reported positive income from the sale of animals) had the highest mean total income $(47,330$ KGS or 686 USD).

\section{Non-livestock-based income}

Tourism-based income sources include household provision of services for locals and foreigner visitors such as accommodation, food and guide services. Other wage income sources come from such occupations as a school teacher or local government administrator, and on-demand labour services (e.g. a driver, farm hand or a construction worker). Tourism was the most popular non-livestock-based method for generating income and provided the highest mean income among the nonlivestock-related sources. Those households engaged in tourism had the highest mean income, followed by those earning other non-livestock income. The mean monthly income of the households engaged in tourism was 50, 330 KGS (729 USD) while livestock-based households earned 17,297 KGS (251 USD). The difference was statistically significant at $1 \%$ level.

In total, 21 households, or a quarter of all households, earned income from tourists. The four herders who herd others' livestock on a fixed salary did not engage in tourism. The share of tourism engagement was different between own-herd households and mixed-herd households paid on a per head basis. Of the own-herd households, $43 \%$ of them engaged in tourism (16 households), 
Table 2 Sources of monthly income by type of household (own-herd vs mixed-herd)

\begin{tabular}{|c|c|c|c|c|c|c|c|c|c|c|c|}
\hline \multirow{3}{*}{$\begin{array}{l}\text { Type of } \\
\text { household } \\
(\mathrm{HH})\end{array}$} & \multirow{3}{*}{$\begin{array}{l}\text { Total } \\
\text { no. } \\
\text { of } \\
\text { HHs }\end{array}$} & \multicolumn{10}{|c|}{ Sources of income, in KGS, by the number of participating households in the activity } \\
\hline & & \multirow{2}{*}{$\begin{array}{l}\text { Herdsman } \\
\text { salary }\end{array}$} & \multirow{2}{*}{$\begin{array}{l}\text { No. } \\
\text { of } \\
\mathrm{HH}\end{array}$} & \multicolumn{4}{|l|}{ Sales of livestock } & \multirow{2}{*}{$\begin{array}{l}\text { Tourism } \\
\text { services }\end{array}$} & \multirow{2}{*}{$\begin{array}{l}\text { No. } \\
\text { of } \\
\mathrm{HH}\end{array}$} & \multirow{2}{*}{$\begin{array}{l}\text { Other } \\
\text { wage } \\
\text { income }\end{array}$} & \multirow{2}{*}{$\begin{array}{l}\text { No. } \\
\text { of } \\
\mathrm{HH}\end{array}$} \\
\hline & & & & Live animal & $\begin{array}{l}\text { No. of } \\
\mathrm{HH}\end{array}$ & $\begin{array}{l}\text { Livestock } \\
\text { products }\end{array}$ & $\begin{array}{l}\text { No. of } \\
\mathrm{HH}\end{array}$ & & & & \\
\hline Own-herd & 26 & & & & 18 & & 13 & & 16 & & 10 \\
\hline Mean & & 0 & 0 & 17,791 (258 USD) & & 9315 (135 USD) & & 37,045 (537 USD) & & $\begin{array}{l}13,950(202 \\
\text { USD) }\end{array}$ & \\
\hline Min & & 0 & & 1000 (14 USD) & & 375 (5 USD) & & 23,333 (338 USD) & & 2000 (29 USD) & \\
\hline Max & & 0 & & $\begin{array}{l}88,750(1,286 \\
\text { USD) }\end{array}$ & & 27,000 (391 USD) & & $\begin{array}{l}150,000(2,174 \\
\text { USD) }\end{array}$ & & $\begin{array}{l}51,000 \text { (739 } \\
\text { USD) }\end{array}$ & \\
\hline $\begin{array}{l}\text { Std. } \\
\text { dev. }\end{array}$ & & 0 & & 21,063 (305 USD) & & 9631 (140 USD) & & 14,310 (207 USD) & & $\begin{array}{l}14,697 \text { (213 } \\
\text { USD) }\end{array}$ & \\
\hline $\begin{array}{l}\text { Mixed- } \\
\text { herd }\end{array}$ & 59 & & 50 & & 51 & & 54 & & 13 & & 14 \\
\hline Mean & & $\begin{array}{l}17,109(248 \\
\text { USD) }\end{array}$ & & 16,796 (243 USD) & & 6712 (97 USD) & & 27,245 (395 USD) & & 7807 (113 USD) & \\
\hline Min & & 1170 (17 USD) & & 291 (4 USD) & & 300 (4 USD) & & 500 (7 USD) & & 500 (7 USD) & \\
\hline $\operatorname{Max}$ & & $\begin{array}{l}56,000(812 \\
\text { USD) }\end{array}$ & & $\begin{array}{l}150,833(2,186 \\
\text { USD) }\end{array}$ & & 26,250 (380 USD) & & 100,000 (1,449 US) & & $\begin{array}{l}27,000 \text { (391 } \\
\text { USD) }\end{array}$ & \\
\hline $\begin{array}{l}\text { Std. } \\
\text { dev. }\end{array}$ & & $\begin{array}{l}12,938 \text { (187 } \\
\text { USD) }\end{array}$ & & 28,562 (414 USD) & & 5958 (86 USD) & & 33,006 (478 USD) & & 8467 (122 USD) & \\
\hline
\end{tabular}

Other wage income is non-livestock-related employment (e.g. teacher) and services wage (e.g. construction labour)

compared with only $13 \%$ (13 households) of the mixedherd households.

Also, the mean on-pasture income of owners $(37,045$ KGS or 537 USD) was higher than the mean tourism earnings of the mixed herders (27,245 KGS or 295 USD), and the difference was statistically significant at the $5 \%$ level.

Overall, the herders can be divided into three categories: poor, rich and in-between. Poor households typically have none or few livestock and herd others' livestock. On average, they manage about 70 livestock units and sell milk at the pastures. In addition, to the livestock income they rarely provide tourism services; as a result in this group only two households provide tourism services.

Rich households typically herd only their own livestock and on average have about 160 livestock units. The richest one had about a thousand livestock units. Most of these households (64\%) also have income from tourism. The in-between group is diverse, and is challenging to categorize strictly based on their livelihood activities.

\section{The loss of pasture productivity perception}

One of the objectives of this study is to see if pasture degradation leads to adoption of non-livestock livelihood, i.e. tourism. If households perceive the pastures to be degraded, it is possible that households, in collaboration with community administrators, could reduce livestock numbers to allow the pastures to recover. Conversely, if a household perceives the pastures to be degraded, but they have no other income-earning alternatives, then that household might continue to undertake herding activities, thus further degrading the pastures. Thus, the perceived state of the pastures could be related to the income diversification strategies taken by some households.

Households were asked whether they thought that 'The Son Kol pastures are degrading due to the high number of livestock'. The response to the Likert-style question gave a score of 1 if the household strongly disagreed and 5 if they strongly agreed. The survey results varied among households and by district. On average, the highest agreement was in Naryn, indicating that herders from Naryn demonstrate the highest concern for the impact of the growing number of livestock and understand the connection of this to loss of pasture productivity. Herders in Kochkor, by contrast, tended to demonstrate the highest mean disagreement. Table 3 compares the state of pasture productivity based on the official data with the households' perception of their pastures.

It is a challenge to make an exact comparison between the official data on the loss of productivity and the households' perceptions, because of the different measurement approaches applied. Nevertheless, in three rayons, the households' perceptions generally coincide with the official data on the loss of productivity. However, despite the official data indicating the highest loss of productivity in Kochkor, the 
Table 3 Comparison of official data and herders' perception on the loss of pasture productivity

\begin{tabular}{lllll}
\hline Rayon/district & Kochkor & Ak Talaa & Naryn & Jumgal \\
\hline Official data & $\begin{array}{l}\text { Mostly medium degradation with } \\
\text { many plots showing severe degradation }\end{array}$ & Mostly slight degradation & Medium degradation & Mostly severe degradation \\
Household perception & Mostly no degradation & Mostly no degradation & $\begin{array}{l}\text { Mostly agree that it is } \\
\text { degraded }\end{array}$ & $\begin{array}{l}\text { Mostly agree that it is } \\
\text { degraded }\end{array}$ \\
Average score & 2.8 & 2.9 & 3.4 & 3.9 \\
\hline
\end{tabular}

households there do not recognize the degradation of their pastures.

\section{Diversification}

\section{Livestock diversification}

The typical herder has sheep, goats, horses and cows. At the rayon level, the largest amount of livestock is in Kochkor and smallest in Jumgal (Table 1). Possession of livestock follows a similar pattern, with sheep and goats constituting the largest share ranging from 82 to $93 \%$. However, the size of the herds differs, with the largest herds in Kochkor (9780) with 287 animals per household and smallest total number in Jumgal (1590) with 72 animals per household.

The livestock diversification index is reported in Fig. 2. The mean Shannon index of 0.5 with a standard deviation of 0.26 shows that the pastoralists have relatively diversified livestock herds.

The livestock diversity distribution is the highest in Jumgal and Kochkor rayons and makes 0.68 and 0.53, respectively. While Ak Talaa and Naryn rayons have less diversified livestock, they have 0.46 and 0.31 respectively because these households tend to have higher share of sheep and goats as compared to other types of livestock. Test of means showed that the difference between rayons was statistically significant at the $5 \%$ level.

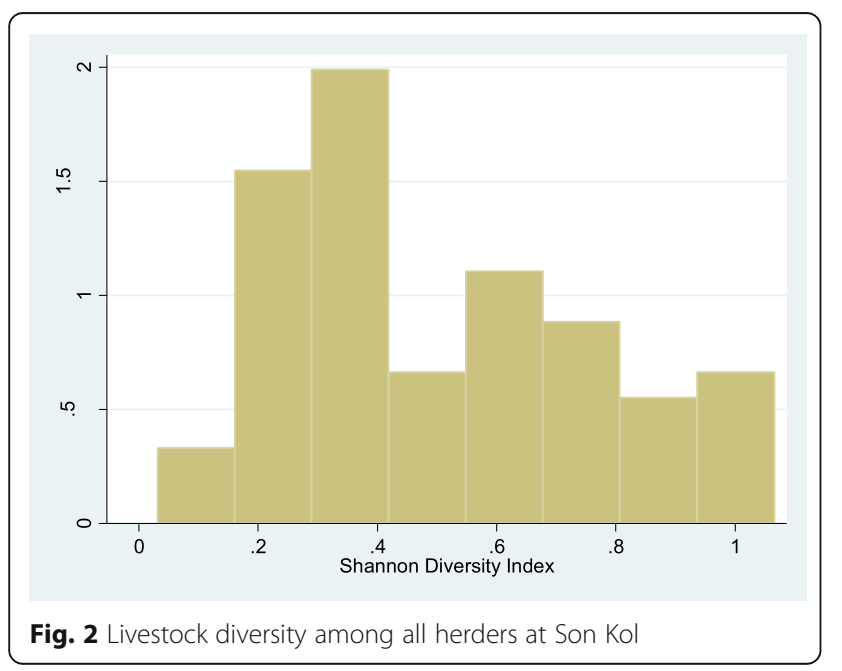

\section{Income diversification}

Table 4 reports the results of the HHI measuring the degree of income diversification by type of household and across rayons. The overall Herfindahl-Hirchmann Index varied between 3427 and 10,000 with a mean of 8613 and standard deviation of 1945 . The mean HHI was the highest in Jumgal rayon and equal to 9223. This indicates that Jumgal is the least diversified in terms of income. The lowest mean index was in Kochkor (8074) suggesting the highest rate of diversification. An ANOVA $t$ test showed that the difference between rayons for the Herfindahl-Hirschman Index was significant at a $1 \%$ level.

When compared using the index, the mean values of the own-herd and mixed-herd groups also varied. The difference between own-herd and mixed-herd households suggests that owners tend to have more diversified livelihood strategies. The $t$ test showed that the difference was significant at the $10 \%$ level. However, the HHI followed the same patterns, so Jumgal's both own and mixed-herd households were least diversified (i.e. highest HHI) and Kochkor's two groups were the most diversified (i.e. lowest HHI). This confirms that the least income diversification occurs in Jumgal, where livestock remains the major income source while Kochkor herders diversify their sources through salaried jobs and tourism.

Table 5 presents the regression results that show the positive relationship between livestock-based income and diversification with significance at 5\% level. However, owners' income diversification increases only up to a certain point as income grows, and then, diversification appears to decrease. A positive coefficient implies that higher diversification is correlated with higher household income and then at certain level it is negative. The pattern also was confirmed by plotting the income quintiles against HHI (Figure 6 in Appendix).

\section{Tourism engagement}

As I have shown earlier, the households who engage in tourism ventures have higher incomes (see the 'Non-livestock-based income' section). Table 6 shows the results of the logistic regression that state the further distance from rayon's centre to the capital and number of others' livestock in the herd decreases 
Table 4 Herfindahl-Hirschman Index across the rayons

\begin{tabular}{clllll}
\hline & Number of households & Mean & Std. dev. & Min & Max \\
\hline Own-herd & 26 & 6853 & 2411 & 2496 & 10,000 \\
Ak Talaa & 3 & 8862 & 2099 & 3869 & 10,000 \\
Jumgal & 12 & 9223 & 1688 & 5008 & 10,000 \\
Naryn & 2 & 8420 & 2088 & 5009 & 10,000 \\
Kochkor & 9 & 8074 & 2027 & 3324 & 10,000 \\
Mixed-herd & 59 & 7797 & 1959 & 2881 & 10,000 \\
Ak Talaa & 14 & 8824 & 2217 & 3869 & 10,000 \\
Jumgal & 10 & 9516 & 1527 & 5168 & 10,000 \\
Naryn & 10 & 8939 & 1841 & 5009 & 10,000 \\
Kochkor & 25 & 8552 & 1754 & 5039 & 10,000 \\
\hline
\end{tabular}

likelihood of the engagement into tourism. The effect of pasture degradation perception was not significant at the $10 \%$ level. So, it suggests that perceiving falling pasture productivity does not lead to adoption of non-livestock income.

\section{Discussion}

The herders in the Son Kol area share the same pastures but use different on-pasture income diversification strategies. The pastoralists mitigate the risks through diversification of livestock composition and adoption of alternative income sources. So, the study used two diversification indicators, one for the composition of livestock and one for income. The results showed that the pastoralists pursued a number of different livelihood strategies and combined livestock-based activities with other income-earning activities.

Households with the least number of head of livestock and located where regional unemployment level is the highest tend to have more diversified livestock composition, but the lowest income diversification levels. A mixture of large and small ruminants, grazers and browsers can optimize the utilization of available resources and minimize their exposure to risk (Nori 2007). So, Jumgal rayon herders showed the highest livestock diversification but the lowest income diversification. This is probably due to a lack of opportunities, as new livelihood strategies require

Table 5 Linear regression of $\mathrm{HHI}$ on the natural logarithm of income. $R$-squared $=0.1$

\begin{tabular}{lll}
\hline Variables & Coefficient & Standard errors \\
\hline Log of income & $6849^{* * *}$ & 2454 \\
Squared log of total income & $-338^{* * *}$ & 116 \\
Constant & $-25308^{* *}$ & 12,867 \\
\hline ** and *** denote significance at the 5\% and 1\% levels, respectively
\end{tabular}

Table 6 Results of logistic regression for tourism engagement with selected variables

\begin{tabular}{|c|c|c|}
\hline Variables & Coefficient & $\begin{array}{l}\text { Standard } \\
\text { errors }\end{array}$ \\
\hline $\begin{array}{l}\text { Distance from rayon's centre to capital (000 } \\
\mathrm{km} \text { ) }\end{array}$ & $-0.874^{* *}$ & 0.447 \\
\hline $\begin{array}{l}\text { Number of others' livestock in herd (100s, in } \\
\text { LU) }\end{array}$ & $-0.564^{* * *}$ & 0.237 \\
\hline Number of own livestock (100s, in LU) & -0.222 & 0.222 \\
\hline $\begin{array}{l}\text { Pasture degradation perception (Likert } \\
\text { scale) }\end{array}$ & 0.148 & 0.579 \\
\hline Constant & 1.489 & 1.655 \\
\hline Pseudo $r^{2}$ & 0.159 & \\
\hline
\end{tabular}

Adding government subsidies to household did not influence the results

** and ${ }^{* * *}$ denote significance at the $10 \%$ and $5 \%$ levels, respectively

investment (Ellis 1999; Gecho 2017). Jumgal is located further from the main markets and also has a high unemployment rate.

Another insight is the heterogeneity between owners and mixed herders. Own-herd households have more diversified incomes than mixed-herd households. Own-herd households tend to have both higher mean incomes and higher diversification of incomes, the latter of which was true for all rayons. The mean incomes from tourism of the own-only herders were also higher. This suggests that herding others' livestock provides income; however, it limits the opportunities to adopt new livelihood strategies both because of lack of free time and because they already earn additional income from the salary for herding.

The share of households engaged in tourism is relatively small, but those households boast the highest incomes. This share is even smaller among mixedherd households. The booming international tourism activity potentially could weaken the heavy reliance on livestock. However, it should be also underlined that, while the mean tourism earnings are high, this source is only available for 2 months of the year, limiting it to only a supplementary livelihood strategy, while livestock-based income is available throughout the year. A smaller distance to market was also associated with a higher likelihood of tourism engagement. This indicates that closer distance to places with high economic activity provides more opportunities for non-agricultural employment.

The relationship between income and income diversification was not linear so the diversification increased as income rose, but after a certain point, it started falling. This is in line with the literature that finds that increasing incomes also leads to an increase of the livestock numbers for the purposes of investment and savings (Schoch et al. 2010). It is safe to conclude that increase of incomes among mixed-herd 
households will lead to their transformation into own-herd household. Another natural question stemming from this is whether, as income increases, ownherd households will continue to increase investment into livestock or will expand into other non-livestock livelihoods?

Further studies with larger samples and more qualitative methods might clarify the relationship between income growth and livestock. Moreover, these findings should be treated cautiously since this study primarily referred to the on-pasture high income. It would be interesting to study more the relationship between income and livestock numbers in the Kyrgyz context.

The assessment of the degradation perception showed that in three rayons, the herders' perceptions generally coincided with the official data on the loss of productivity. Only in one rayon (Kochkor) was the perception different from the official data. This is important because there is a discussion, both in the literature and empirical work, about the validity of the official data. The results do not claim to evaluate the accuracy of the official data, but the herders' perceptions of the degree of pasture degradation largely support the official accounts.

Interestingly, the high perception of pasture degradation did not lead to more adoption of the non-livestock income, namely, tourism. Therefore, it seems that herders acknowledge the decline of the major natural resource but are reluctant or unable to adopt any new livestock livelihood strategy. This finding is also in line with the literature that finds the widening gap between policy-makers and pasture users (Kasymov et al. 2016), so dependence of pasture productivity on the pastoralists' well-being is not well communicated or at least neglected. It is hard to tell why this is happening. On the other hand, declining pasture productivity does not reduce the herding fees, as looking after others' livestock has been a long-standing practice in Kyrgyz communities, and the results suggest that now it impedes household engagement into tourism. On the other hand, Ouedraogo and Davies (2016) suggest that pastoralists' cultural norms may prevent adopting new income sources. Therefore, in the case of the Son Kol households, herding others' livestock is a well-established way of life, and even higher profits of tourism are not sufficient to change the habit.

The findings of the study suggest that the adoption of non-livestock livelihood options, even on pasture, is a complex issue entangled with individual circumstances, regional features and perhaps cultural norms. Income diversification requires a raise in income from the traditional ways and gradual adoption of the new income sources. However, external inputs such as provision of capacity-building investments and raising awareness about alternative livelihood sources could potentially increase the adoption of the new incomes.

The globally growing pasture-based tourism will certainly bring many new opportunities for the pastoralist communities in Kyrgyzstan and Central Asia. However, the benefits may not affect everyone equally, so the traditional herding-based households are less likely to profit whereas more income-independent (e.g. have own livestock) communities with better access to the central markets will enjoy increasing revenues.

\section{Conclusion}

As this study has demonstrated, adoption of nonlivestock-based income can be an important household livelihood strategy. Specifically, the provision of tourism services can greatly contribute to the well-being of the pastoralist communities in Kyrgyzstan, namely, provide higher incomes and potentially reduce pressure on pastures. However, the adoption of new income sources depends on individual household and regional features. In addition, the study also found no link between household's concern about decreasing pasture productivity and adoption of non-livestock income. The results of the study could be used for lobbying about tourism benefits in pastoralist societies and decreasing reliance on the livestock.

\section{Policy recommendations}

Any diversification policy should account for individual household features such as the share of reliance on livestock. In addition, it is important to distinguish between the own-only herd owners who have more diversified incomes, while the poorer households who rely mainly on livestock pursue livestock diversification. Moreover, the results suggest that families with higher on-pasture income tend to have mutiple income strategies more often, indicating that any new policy should aim to aid income diversification among the poorest households who also rely mainly on a singe income source.

The results also suggest that tourism adoption is also related to the district infrastructure features such as roads granting access to high areas of high economic activity. Only the government can provide these. Hence, policy-makers' efforts to reduce pressure on pastures should include off-pasture infrastructure development.

To my knowledge, this is the first study on on-pasture income diversification factors among pastoralists in Kyrgyzstan, and perhaps in Central Asia. Future studies could benefit from the inclusion of data such as the education of the household members, the quality of the roads, access to loans and whether household members have participated in training programmes on nonlivestock-based income opportunities. 


\section{Appendix}
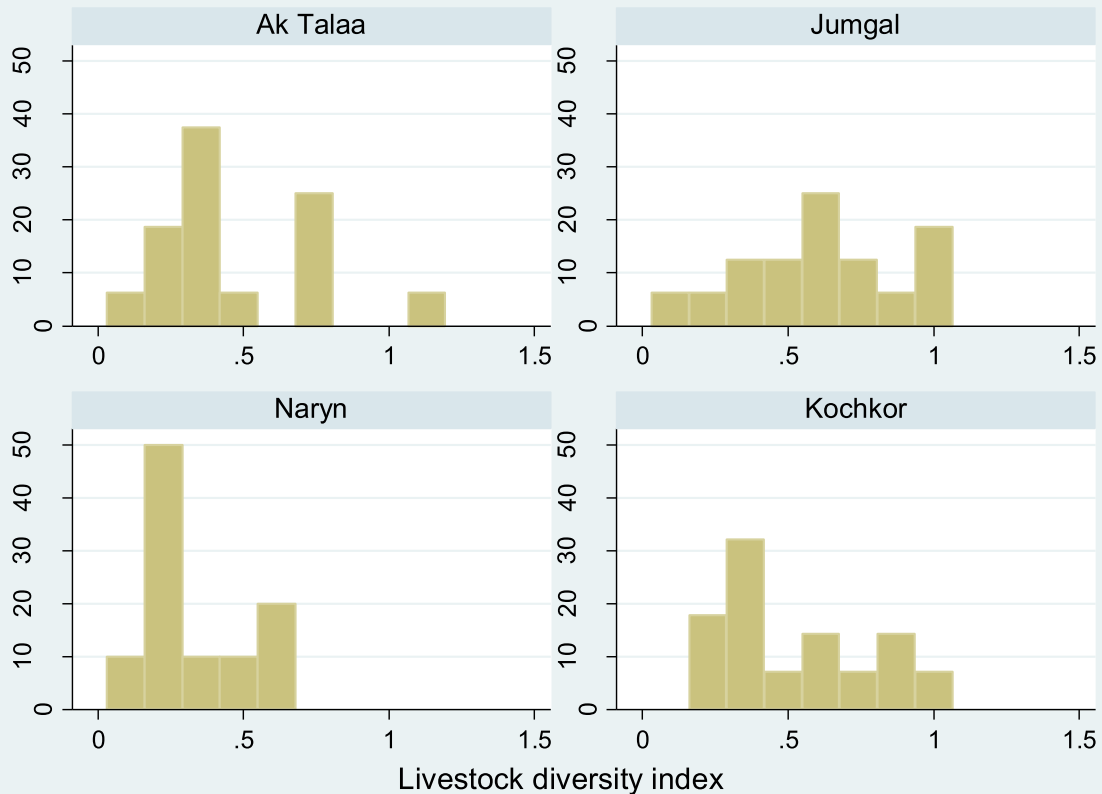

Fig. 3 Shannon diversity index distribution across rayons (in percentage)
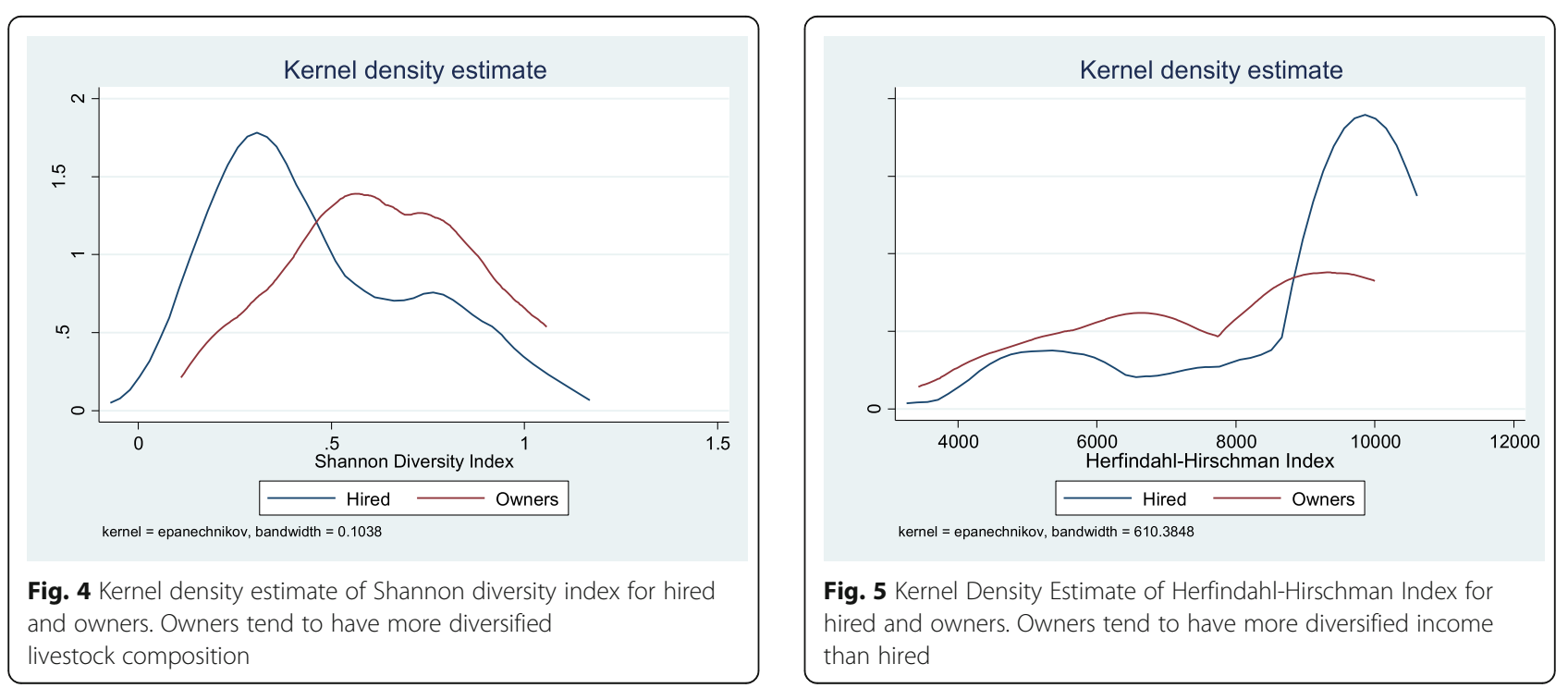


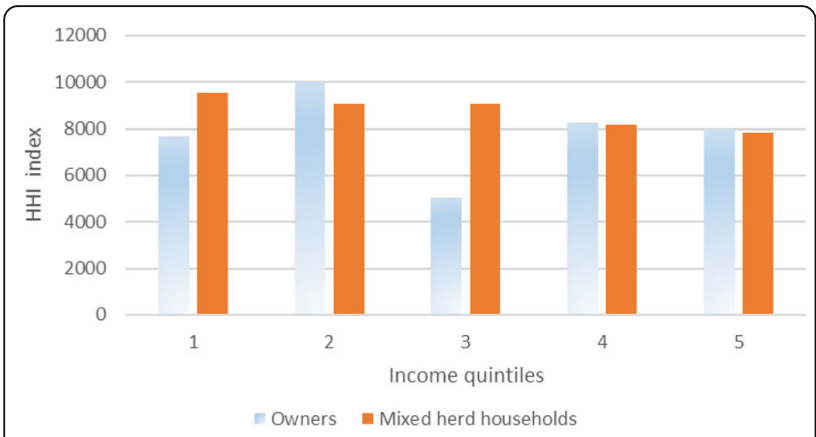

Fig. 6 Herfindahl-Hirschman Index among income quintiles between own-only and mixed herd households

\section{Acknowledgements}

I am grateful to the six field survey assistants and members of the local government for all their support during the data collection and beyond. I am grateful to Professor Roberto Garcia for his guidance and to Alessandra Sztrimbely for proofreading the manuscript. I thank anonymous reviewers whose comments and suggestions greatly improved the paper.

\section{Author's contributions}

The author read and approved the final manuscript.

\section{Funding}

Field data collection was funded by the Economics of Land Degradation Initiative (ELD) as part of a project hosted by Deutsche Gesellschaft für Internationale Zusammenarbeit (GIZ) GmbH (German Federal Enterprise for International Cooperation).

\section{Availability of data and materials}

The original survey materials were in Kyrgyz and translated into English. The datasets generated during and/or analysed during the current study are available from the corresponding author on reasonable request.

\section{Ethics approval and consent to participate}

The study followed the Ethical guidelines for NMBU which was adopted by the University Board on 26 November 2015 (UB case 111/2015) and was conducted under supervision of the Economics of Land Degradation Initiative. All participants of this study granted consent to participate and fully understood that results of this study could be published.

\section{Consent for publication}

Not applicable.

\section{Competing interests}

The author declares that he has no competing interests.

\section{Received: 28 December 2018 Accepted: 21 August 2019}

Published online: 11 October 2019

\section{References}

Addisu, Yilebes. 2017. Livelihood strategies and diversification in western tip pastoral areas of Ethiopia. Pastoralism 7 (1) https://doi.org/10.1186/s13570017-0083-3.

Boncinelli, F., F. Bartolini, and L. Casini. 2018. Structural factors of labour allocation for farm diversification activities. Land Use Policy 71 (January 2016): 204-212 https://doi.org/10.1016/j.landusepol.2017.11.058.

Christianen, M.J.A., P.M.J. Herman, T.J. Bouma, L.P.M. Lamers, M.M. van Katwijk, T. van der Heide, P.J. Mumby, et al. 2014. Habitat collapse due to overgrazing threatens turtle conservation in marine protected areas. Proceedings of the Royal Society B: Biological Sciences 281 (1777): 20132890-20132890 https://doi.org/10.1098/rspb.2013.2890.

Davies, Jonathan, and Richard Hatfield. 2007. The economics of mobile pastoralism: A global summary. Nomadic Peoples 11 (1): 91-116 https:// doi.org/10.3167/np.2007.110106.
Dinku, Amare Molla. 2018. Determinants of livelihood diversification strategies in Borena pastoralist communities of Oromia Regional State, Ethiopia. Agriculture and Food Security 7 (1): 1-8 https://doi.org/10. 1186/s40066-018-0192-2.

Dörre, Andrei. 2015. Promises and realities of community-based pasture management approaches: Observations from Kyrgyzstan. Pastoralism 5 (1) https://doi.org/10.1186/s13570-015-0035-8.

Ellis, Frank. 1999. Rural livelihood diversity in developing countries: Evidence and policy implications, Natural Resource Perspectives, no. 40. Norwich: Overseas Development Institute, University of East Anglia.

Gaitán, Juan J., Donaldo E. Bran, Gabriel E. Oliva, Martín R. Aguiar, Gustavo G. Buono, Daniela Ferrante, Viviana Nakamatsu, et al. 2018. Aridity and overgrazing have convergent effects on ecosystem structure and functioning in Patagonian rangelands. Land Degradation \& Development 29 (2): 210-218 https://doi.org/10.1002/ldr.2694.

Gecho, Yishak. 2017. Rural farm households' income diversification: The case of Wolaita Zone, Southern Ethiopia. Social Sciences 6 (2): 45 https://doi.org/10.11648/j.ss.20170602.12.

Genovese, Dino, Francesca Culasso, Elisa Giacosa, and Luca Maria Battaglini. 2017. Can livestock farming and tourism coexist in mountain regions? A new business model for sustainability. Sustainability 9 (11): 2021 https://doi.org/10.3390/su9112021.

Goody, Jack. 1972. The evolution of the family. In Household and family in past time, ed. Peter Laslett and R. Wall, 103-124. Cambridge: Cambridge University Press https://doi.org/10.1017/CBO9780511561207.005.

Haggblade, S., P. Hazell, and T. Readron. 2009. Transforming the rural nonfarm economy: Opportunities and threats in the developing world. International Food Policy Research Institute. https://doi.org/10.1093/ ajae/aap027.

Hardin, Garret. 1968. The tragedy of the commons. Science 162 (3859): 1243-1248 https://doi.org/10.1126/science.162.3859.1243.

Hauck, Markus, Gulzhan T. Artykbaeva, Tamara N. Zozulya, and Choimaa Dulamsuren. 2016. Pastoral livestock husbandry and rural livelihoods in the forest-steppe of East Kazakhstan. Journal of Arid Environments 133 (October): 102-111 https://doi.org/10.1016/j.jaridenv.2016.05.009.

Hilker, Thomas, Enkhjargal Natsagdorj, Richard H. Waring, Alexei Lyapustin, and Yujie Wang. 2014. Satellite observed widespread decline in Mongolian grasslands largely due to overgrazing. Global Change Biology 20 (2): 418-428 https://doi.org/10.1111/gcb.12365.

Hirschmann, A.O. 1964. The paternity of an index. American Economic Review 54 (5): 761-762.

llibezova, E., L. llibezova, R. Toktosynov, and E. Selezneva. 2005. Suusamyr Valley household survey. Bishkek: http://www.caresd.net/img/docs/en/1609.pdf.

IPBES. 2018. 75\% of Earth's land areas are degraded,. https://news. nationalgeographic.com/2018/03/ipbes-land-degradation-environmentaldamage-report-spd/.

Kairis, Orestis, Christos Karavitis, Luca Salvati, Aikaterini Kounalaki, and Kostas Kosmas. 2015. Exploring the impact of overgrazing on soil erosion and land degradation in a dry Mediterranean agro-forest landscape (Crete, Greece). Arid Land Research and Management 29 (3): 360-374 https://doi.org/10.1080/ 15324982.2014.968691.

Kasymov, U., A. Undeland, A. Dorre, and A. Mackinnon. 2016. Central Asia: Kyrgyzstan and the learning experience in the design of pastoral institutions. Revue Scientifique et Technique de l'OIE 35 (2): 511-521 https:/doi.org/10.20506/rst.35.2.2538.

Kerven, Carol, Sarah Robinson, Roy Behnke, Kanysh Kushenov, and E.J. Milner-Gulland. 2016. Horseflies, wolves and wells: Biophysical and socioeconomic factors influencing livestock distribution in Kazakhstan's rangelands. Land Use Policy 52: 392-409 https://doi.org/10.1016/j. landusepol.2015.12.030.

Kerven, Carol, Bernd Steimann, Laurie Ashley, Chad Dear, and Inam ur Rahim. 2011. Pastoralism and farming in Central Asia's mountains: A research review. Bishkek: http://www.ucentralasia.org/downloads/pastoralism_and_farming_ in_central_asia_mountains.

Land Cadastra of the Kyrgyz Republic. 2015. Land use in the Kyrgyz Republic. State Registration Serice of the Kyrgyz Republic (SRS KR), Bishkek.

Laslett, Peter, and R. Wall, eds. 1972. Household and family in past time. Cambridge: Cambridge University Press https://doi.org/10.1017/CBO9780511561207.

Levine, Jordan, Aiganysh Isaeva, lan Eddy, Marc Foggin, Sarah Gergel, Shannon Hagerman, and Hisham Zerriffi. 2017. A cognitive approach to the post-Soviet Central Asian pasture puzzle: New data from Kyrgyzstan. Regional Environmental Change 17 (3): 941-947 https://doi.org/10.1007/s10113-017-1122-8. 
Liao, Chuan, Christopher Barrett, and Karim Aly Kassam. 2015. Does diversification improve livelihoods? Pastoral households in Xinjiang, China. Development and Change 46 (6): 1302-1330 https://doi.org/10. 1111/dech.12201.

Liechti, Karina. 2012. Значения Пастбищ в Спорах о Деградации Ресурсов: Доказательства Из Сельской Местности Постсоциалистического Кыргызстана/Pasture values in resource degradation disputes: Evidence from rural post-socialist Kyrgyzstan. Mountain Research and Development 32 (3RU): R51-R61 https://doi.org/ 10.1659/MRD-JOURNAL-D-11-00113.1.ru.

Liu, Zhen, and Jing Lan. 2015. The sloping land conversion program in China: Effect on the livelihood diversification of rural households. World Development 70: 147-161 https://doi.org/10.1016/j.worlddev.2015.01.004.

Ludi, Eva. 2004. Management of high pastures under changing socio-economic conditions in Kyrgyzstan. Bern: Cen tre for Development and Environment (CDE) https://doi.org/10.1659/0276-4741(2003)023[0119:SPMIKA]2.0.CO;2.

Martin, Sarah M., and Kai Lorenzen. 2016. Livelihood diversification in rural Laos. World Development 83: 231-243 https://doi.org/10.1016/j.worlddev.2016.01.018.

Mirzabaev, Alisher, Mohamed Ahmed, Jutta Werner, John Pender, and Mounir Louhaichi. 2016. Rangelands of Central Asia: Challenges and opportunities. Journal of Arid Land 8 (1): 93-108 https://doi.org/10.1007/s40333-015-0057-5.

Nori, M. 2007. Mobile livelihoods, patchy resources \& shifting rights: Approaching pastoral territories. Rome: http://www.hubrural.org/Mobile-livelihoods-patchy. html?lang=fr.

O'Mara, F.P. 2012. The role of grasslands in food security and climate change. Annals of Botany 110 (6): 1263-1270 https://doi.org/10.1093/aob/mcs209.

Ouedraogo, R., and J. Davies. 2016. Enabling sustainable pastoralism: Policies and investments that optimise livestock production and rangeland stewardship. Revue Scientifique et Technique de l'OIE 35 (2): 619-630 https://doi.org/10. 20506/rst.35.2.2544.

Pasture Department. 2015. Деградация Пастбищных Земель в Кыргызстане Составляет До 70\%. http://knews.kg/2015/02/degradatsiya-pastbischnyihzemel-v-kyirgyizstane-sostavlyaet-do-70/

Preston, David, Jamie Fairbairn, Narel Paniagua, Glenn Maas, Martha Yevara, and Stephan Beck. 2003. Grazing and environmental change on the Tarija Altiplano, Bolivia. Mountain Research and Development 23 (2): 141-148 https://doi.org/10.1659/0276-4741(2003)023[0141:GAECOT]2.0.CO;2.

Quillerou, E., R. Thomas, O. Guchgeldiev, S. Ettling, H. Etter, and N. Stewart. 2016. Economics of land degradation (ELD) initiative: Broadening options for improved economic sustainability in Central Asia. Synthesis Report. Amman: www.eld-initiative.org.

Robinson, S. 2016. Land degradation in Central Asia: Evidence, perception and policy, 451-490 https://doi.org/10.1007/978-3-642-16014-1_17.

Robinson, S., C. Kerven, R. Behnke, K. Kushenov, and E.J. Milner-Gulland. 2016. The changing role of bio-physical and socio-economic drivers in determining livestock distributions: A historical perspective from Kazakhstan. Agricultural Systems 143 (February): 169-182 https://doi.org/10.1016/j.agsy.2015.12.018.

Rosenbluth, Gideon. 1955. Measures of concentration. In Business concentration and price policy, ed. George Stigler, 57-99. National Bureau of Economic Research, Inc https://econpapers.repec.org/RePEc:nbr:nberch:0953.

Schauer, Mark, Pushpam Kumar, Aaron Vuola, Mesfin Tilahun, Eric Mungatana, et al. 2015. The economics of land degradation in Africa. Bonn: www.eldinitiative.org.

Schier, Michaela, Nicola Hilti, Helmut Schad, Cornelia Tippel, Andrea DittrichWesbuer, and Anna Monz. 2015. Residential multi-locality studies - the added value for research on families and second homes. Tijdschrift voor Economische en Sociale Geografie 106 (4): 439-452 https://doi.org/10.1111/tesg.12155.

Schoch, Nadia, Bernd Steimann, and Susan Thieme. 2010. Migration and animal husbandry: Competing or complementary livelihood strategies. Evidence from Kyrgyzstan. Natural Resources Forum 34 (3): 211-221 https://doi.org/10. 1111/j.1477-8947.2010.01306.x

Semenova, T.B., and T.Dzh Chortonbaev. 2014. Importance and current state of mountain pastures of Kyrgyzstan Znacheniye i Sovremennoyoe Sostoyaniye Gornyh Pastbish Kyrgyzstana. Vestnik KNAU 1 (30): 162-164.

Shannon, C.E., and W. Weaver. 1949. The mathematical theory of communication Urbana: The University of Illinois Press, Urbana.

Smith, Pete. 2014. Do grasslands act as a perpetual sink for carbon? Global Change Biology 20 (9): 2708-2711 https://doi.org/10.1111/gcb.12561.

Sneath, David. 2003. Land use, the environment and development in postsocialist Mongolia. Oxford Development Studies 31 (4): 441-460 https://doi. org/10.1080/1360081032000146627.
Spellerberg, lan F., and Peter J. Fedor. 2003. A tribute to Claude Shannon (19162001) and a plea for more rigorous use of species richness, species diversity and the 'Shannon-wiener' index. Global Ecology and Biogeography 12 (3): 177-179 https://doi.org/10.1046/j.1466-822X.2003.00015.x.

Stevens, Nicola, B.F.N. Erasmus, S. Archibald, and W.J. Bond. 2016. Woody encroachment over 70 years in South African savannahs: Overgrazing, global change or extinction aftershock? Philosophical Transactions of the Royal Society, B: Biological Sciences 371 (1703): 20150437 https://doi.org/10.1098/ rstb.2015.0437.

Tarrasón, D., F. Ravera, M.S. Reed, A.J. Dougill, and L. Gonzalez. 2016. Land degradation assessment through an ecosystem services lens: Integrating knowledge and methods in pastoral semi-arid systems. Journal of Arid Environments 124: 205-213 https://doi.org/10.1016/j.jaridenv.2015.08.002.

Thieme, Susan. 2014. Coming home? Patterns and characteristics of return migration in Kyrgyzstan. International Migration 52 (5): 127-143 https://doi. org/10.1111/j.1468-2435.2011.00724.x.

Tilekeyev, Kanat, Roman Mogilevskii, Aida Bolotbekova, and Shoola Dzhumaeva. 2016. Sheep meat production value chains in the Kyrgyz Republic and export capacity to the EAEU member states. Bishkek: Insitute of Public Policy and Administration of the University of Central Asia.

Watson, D.J., and J. van Binsbergen. 2013. Livelihood diversification opportunities for pastoralists in Turkana, Kenya. ILRI Research Report 5: 1-37 https://doi.org/ 10.1017/CBO9781107415324.004.

Weichhart, Peter. 2015. Residential multi-locality: In search of theoretical frameworks. Tijdschrift voor Economische en Sociale Geografie 106 (4): 378-391 https://doi.org/10.1111/tesg.12156.

Zhumanova, Munavar, Nicole Wrage-Mönnig, and Dietrich Darr. 2016. Farmers' decision-making and land use changes in Kyrgyz agropastoral systems. Mountain Research and Development 36 (4): 506-517 https://doi.org/10.1659/ MRD-JOURNAL-D-16-00030.1.

Zika, Michael, and Karl Heinz Erb. 2009. The global loss of net primary production resulting from human-induced soil degradation in drylands. Ecological Economics 69 (2): 310-318 https://doi.org/10.1016/j.ecolecon.2009.06.014.

\section{Publisher's Note}

Springer Nature remains neutral with regard to jurisdictional claims in published maps and institutional affiliations.

\section{Submit your manuscript to a SpringerOpen ${ }^{\circ}$ journal and benefit from:}

- Convenient online submission

- Rigorous peer review

- Open access: articles freely available online

High visibility within the field

- Retaining the copyright to your article

Submit your next manuscript at $\boldsymbol{\nabla}$ springeropen.com 